\title{
PENGARUH MOTIVASI, TINGKAT PENDIDIKAN, DAN SOSIALISASI DALAM MENDORONG KEMAUAN WAJIB PAJAK MENGIKUTI PENGAMPUNAN PAJAK (Studi Kasus Pada Kantor Pelayanan Pajak Pratama Manado)
}

\author{
Kartini Merdekawati Assa ${ }^{1}$, Jenny Morasa ${ }^{2}$, Rudy J. Pusung ${ }^{3}$ \\ ${ }^{1,2,3}$ Fakultas Ekonomi dan Bisnis . Jurusan Akuntansi. Universitas Sam Ratulangi, Jl. Kampus Bahu, Manado, \\ 95115, Indonesia \\ E-mail :kartini.assa@yahoo.com
}

\begin{abstract}
Tax Amnesty is an Indonesian government's program that aims to accelerate Indonesian economy through wealth transfer and tax ransom payment from the taxpayers. The tax amnesty is tax abolition that should be owed, not subjected to administrative sanctions and tax penalties by reveal the wealth and pay the ransom. The objective of this study is to determine the influence of motivation, education level and socialization on the willingness to participate in tax amnesty in Manado Tax Office. This study used multiple linear regression method with SPSS version 20.0. The population is taken from the taxpayer that participated tax amnesty program in Manado Tax Office and the sample used in this study amounted to 100 taxpayers. The result showed that motivation, education level and socialization have an influence on the willingness to participate in tax amnesty.
\end{abstract}

Keywords: motivation, education level, socialization, tax amnesty

\section{PENDAHULUAN}

Pemerintah Indonesia berupaya untuk meningkatkan penerimaan pajak mengeluarkan Undang-Undang Pengampunan Pajak Nomor 11 Tahun 2016 pada tanggal 1 Juli 2016. Pemerintah Indonesia mencanangkan Program Pengampunan Pajak yang bertujuan untuk mempercepat pertumbuhan ekonomi Indonesia melalui pengalihan harta dan pembayaran uang tebusan pajak dari masyarakat. Istilah "Pengampunan Pajak" disebut dalam peraturan perundang-undangan, sedangkan pemerintah mensosialisasikan sebagai "Amnesty Pajak". Sementara banyak orang yang menyebutnya "Tax Amnesty". Untuk mempermudah dalam melakukan sosialisasi DJP memilih slogan "Ungkap, Tebus, Lega", sehingga WP dapat lebih cepat dan mudah memahaminya. Slogan tersebut diambil dari definisi pengampunan pajak dalam undang-undang, yaitu penghapusan pajak yang seharusnya terutang, tidak dikenakan sanksi administrasi dan sanksi pidana perpajakan cara mengungkapkan harta dan membayar uang tebusan.

Sejak reformasi fiskal pada tahun 1984 dalam pemungutan pajak, Negara memberlakukan self assessment system. Sistem ini mensyaratkan adanya peran aktif dari setiap WP untuk memenuhi kewajiban perpajakannya. Program pengampunan pajak memerlukan kemauan dari WP untuk mengakui kesalahannya sehingga dapat diberikan pengampunan atas kewajiban perpajakan sepanjang WP telah memenuhi persyaratan yang telah ditentukan. Kemauan merupakan hal yang sangat penting dan mendasar dalam menyukseskan pelaksanaan program pengampunan pajak. Oleh karena itu, sangat penting apabila kemauan mengikuti pengampunan pajak oleh WP dapat timbul dari dalam diri individu secara sukarela. Kemauan untuk mengikuti pengampunan pajak dapat dipengaruhi oleh berbagai faktor, seperti motivasi, tingkat pendidikan, dan sosialisasi. Motivasi dan tingkat pendidikan WP merupakan faktor dari dalam diri setiap WP, serta sosialisasi merupakan faktor dari luar yang mendorong kemauan WP mengikuti pengampunan pajak. (Putri, 2016) 
Berdasarkan latar belakang, maka rumusan masalah dalam penelitian ini adalah sebagai berikut :

1. Apakah Motivasi berpengaruh terhadap Kemauan Wajib Pajak Mengikuti Pengampunan Pajak di KPP Pratama Manado?

2. Apakah Tingkat Pendidikan berpengaruh terhadap Kemauan Wajib Pajak Mengikuti Pengampunan Pajak di KPP Pratama Manado?

3. Apakah Sosialisasi berpengaruh terhadap Kemauan Wajib Pajak Mengikuti Pengampunan Pajak di KPP Pratama Manado?

Berdasarkan rumusan masalah yang ada, maka tujuan dalam penelitian ini adalah se bagai berikut.

1. Mengetahui pengaruh Motivasi terhadap Kemauan Wajib Pajak Mengikuti Pengampunan Pajak di KPP Pratama Manado.

2. Mengetahui pengaruh Tingkat Pendidikan terhadap Kemauan Wajib Pajak Mengikuti Pengampunan Pajak di KPP Pratama Manado.

3. Mengetahui pengaruh Sosialisasi terhadap Kemauan Wajib Pajak Mengikuti Pengampunan Pajak di KPP Pratama Manado

\section{TINJAUAN PUSTAKA}

\subsection{Landasan Teori}

\subsubsection{Akuntansi Pajak}

Akuntansi pajak (tax accounting) membahas peraturan perpajakan serta transaksi akuntansi penting yang berkaitan tujuan menentukan pajak minimum yang dapat dicapai dalam batas-batas yang diperkenankan oleh undang-undang atau peraturan perpajakan (Suwardjono, 2014:39).

\subsubsection{Teori Dasar Pajak}

\subsubsection{Pengertian Pajak}

Menurut Soemitro, pajak adalah iuran rakyat kepada kas negara berdasarkan undangundang (yang dapat dipaksakan) tiada mendapat jasa timbal (kontraprestasi) yang langsung dapat ditunjukkan dan digunakan untuk membayar pengeluaran umum (Mardiasmo, 2016:1)

\subsubsection{Sistem Pemungutan Pajak}

1. Official Assessment System

2. Self Assessment System

3. Withholding System

\subsubsection{Wajib Pajak}

Wajib pajak merupakan bagian terpenting dalam perpajakan. Undang-Undang No. 16 tahun 2009 Pasal 1 menyebutkan bahwa WP adalah orang pribadi atau badan, yang meliputi pembayar pajak, pemotong pajak dan pemungut pajak, yang mempunyai hak dan kewajiban perpajakan sesuai ketentuan peraturan perundang-undangan perpajakan (Sumarsan,2013:19).

\subsubsection{Pengampunan Pajak}

\subsubsection{Pengertian Pengampunan Pajak}

Berdasarkan Pasal 1 butir 1 Undang-Undang Nomor 11 Tahun 2016, yang dimaksud pengampunan pajak adalah penghapusan pajak yang seharusnya terutang, tidak dikenai sanksi administrasi perpajakan dan sanksi pidana di bidang perpajakan, cara mengungkapkan harta dan membayar uang tebusan (Sakti,2016:4).

\subsubsection{Asas Pengampunan Pajak}

Berdasarkan ketentuan dalam Undang-Undang Nomor 11 Tahun 2016, pengampunan pajak dilaksanakan berdasarkan asas; Kepastian hukum, Keadilan, Kemanfaatan, dan Kepentingan nasional. 


\subsubsection{Tujuan Pengampunan Pajak}

Sesuai Penjelasan Undang-Undang Nomor 11 Tahun 2016, pengampunan pajak diterapkan di Indonesia bertujuan untuk:

1. Mempercepat pertumbuhan dan retrukturisasi ekonomi melalui pengalihan harta, yang antara lain akan berdampak terhadap peningkatan likuiditas domestik, perbaikan nilai tukar rupiah, penurunan suku bunga, peningkatan investasi;

2. Mendorong reformasi perpajakan menuju sistem perpajakan yang lebih berkeadilan serta perluasan basis data perpajakan yang lebih valid, komprehensif, dan terintegritasi; serta

3. Meningkatkan penerimaan pajak, yang antara lain akan digunakan untuk pembiayaan pembangunan.

\subsubsection{Subjek dan Objek Pengampunan Pajak}

WP yang berhak untuk mendapatkan pengampunan pajak adalah WP yang mempunyai kewajiban menyampaikan SPT Tahunan PPh. demikian, WP status bendahara dan joint operation tidak termasuk pihak yang bisa mendapatkan pengampunan pajak. Secara lengkap, Wajib Pajak yang bisa memperoleh pengampunan pajak, yaitu : WP Orang Pribadi, WP Badan, WP yang Bergerak di bidang Usaha Mikro Kecil dan Menegah (UMKM), dan Orang Pribadi atau Badan yang belum menjadi WP

Objek pengampunan pajak meliputi pengampunan atas kewajiban perpajakan sampai akhir tahun pajak yang berakhir pada jangka waktu 1 Januari 2015 sampai 31 Desember 2015 bagi yang belum atau belum sepenuhnya diselesaikan oleh WP. Kewajiban perpajakan yang dimaksud adalah kewajiban atas PPh, PPN, dan PPnBM .

\subsubsection{Kemauan Mengikuti Pengampunan Pajak}

Kemauan merupakan suatu dorongan dari dalam yang sadar, berdasarkan pertimbangan pikir, perasaan, serta seluruh pribadi seseorang yang menimbulkan kegiatan yang terarah pada tercapainya tujuan tertentu yang berhubungan kebutuhan hidup. Jadi kemauan adalah dorongan dalam diri seseorang, berdasarkan pertimbangan pemikiran dan perasaan yang menimbulkan suatu kegiatan untuk tercapainya tujuan tertentu (Nugroho, 2016).

\subsubsection{Motivasi}

Motivasi adalah kekuatan potensial yang ada dalam diri WP yang melatarbelakangi seorang WP untuk membayar pajak. Motivasi ini bisa timbul dari dalam maupun luar individu. Motivasi membayar pajak seorang WP yang berasal dari luar WP adalah adanya dorongan dari aparat pajak, lingkungan kerja, teman atau kerabat yang mendorongnya untuk membayar pajak.

\subsubsection{Tingkat Pendidikan}

Pendidikan berasal dari kata "didik", lalu kata ini mendapat awalan me- sehingga menjadi "mendidik", artinya memelihara dan memberi latihan. Menurut KBBI, pendidikan adalah proses pengubahan sikap dan tata laku seseorang atau sekelompok orang dalam usaha mendewasakan manusia melalui upaya pengajaran dan pelatihan. Dalam pengertian yang luas, pendidikan dapat diartikan sebagai sebuah proses metode-metode tertentu sehingga orang memperoleh pengetahuan, pemahaman, dan cara bertingkah laku yang sesuai kebutuhan (Maryati, 2014).

\subsubsection{Sosialisasi}

Sosialisasi adalah suatu kegiatan atau upaya yang dilakukan oleh seorang atau organisasi tertentu memberitahukan sesuatu (informasi) untuk diketahui oleh umum atau kalangan tertentu. Sosialisasi perpajakan merupakan suatu upaya DJP khususnya kantor pelayanan pajak untuk memberikan pengertian, informasi, dan pembinaan kepada masyarakat 
mengenai segala sesuatu yang berhubungan perpajakan dan perundang-undangan perpajakan (Rohmawati dan Rasmini, 2012)

\subsection{Kerangka Pemikiran}

Gambar 2.1 Kerangka Pemikiran

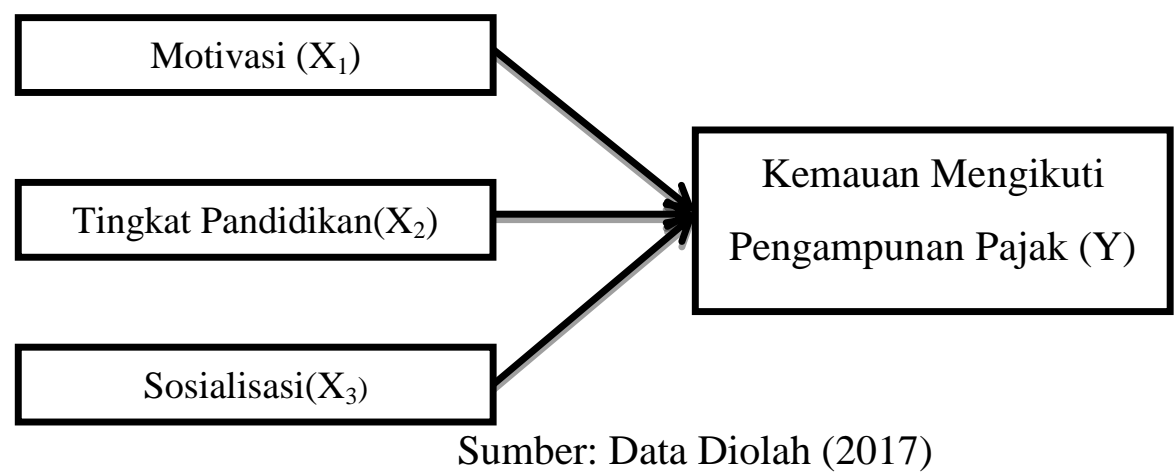

\subsection{Hipotesis}

$\mathrm{H}_{1}$ : Motivasi berpegaruh terhadap Kemauan Wajib Pajak Mengikuti Pengampunan Pajak di KPP Pratama Manado.

$\mathrm{H}_{2}$ : Tingkat Pendidikan berpengaruh terhadap Kemauan Wajib Pajak Mengikuti Pengampunan Pajak di KPP Pratama Manado.

$\mathrm{H}_{3}$ : Sosialisasi berpegaruh terhadap Kemauan Wajib Pajak Mengikuti Pengampunan Pajak di KPP Pratama Manado.

\subsection{Penelitian Terdahulu}

1. Roralita Lukmana Putri (2016) dengan judul Pengaruh Motivasi Membayar Pajak dan Tingkat Pendidikan Terhadap Kepatuhan Wajib Pajak Orang Pribadi Pada Kantor Wilayah Direktorat Jenderal Pajak Daerah Istimewa Yogyakarta Tahun 2015. Tujuan penelitian menganalisis apakah motivasi membayar pajak dan tingkat pendidikan berpengaruh terhadap kepatuhan WP OP dalam membayar pajaknya. Metode analisis kuantitatif. Hasil penelitian menunjukkan bahwa motivasi membayar pajak dan tingkat pendidikan berpengaruh secara signifikan terhadap kepatuhan WP OP.

2. Eka Maryati (2014) ) dengan judul Pengaruh Sanksi Pajak, Motivasi Dan Tingkat Pendidikan Terhadap Kepatuhan Wajib Pajak (Studi Pada Wilayah Kantor Pelayanan Pajak Pratama Bintan). Tujuan penelitian menganalisis ada atau tidaknya pengaruh sanksi pajak, motivasi, dan tingkat pendidikan terhadap kepatuhan WP baik secara parsial ataupun simultan. Metode analisis kuantitatif. Hasil penelitian menunjukkan bahwa sanksi pajak tidak berpengaruh secara parsial terhadap kepatuhan WP. Motivasi dan tingkat pendidikan berpengaruh secara parsial terhadap kepatuhan WP.

\section{METODE PENELITIAN}

\subsection{Jenis Penelitian}

Jenis penelitian ini adalah penelitian kuantitatif bersifat deskriptif dengan menggunakan analisis linier berganda.

\subsection{Tempat dan Waktu Penelitian}

Penelitian ini dilakukan di Kantor Pelayanan Pajak Pratama Manado. Waktu penelitian dilaksanakan pada bulan April sampai Agustus 2017.

\subsection{Populasi dan Sampel Penelitian}


Populasi adalah wilayah generalisasi yang terdiri atas obyek/subjek yang mempunyai kualitas dan karakteristik tertentu yang ditetapkan oleh peneliti untuk dipelajari dan kemudian ditarik kesimpulannya (Sugiyono,2014:115). Populasi penelitian ini adalah seluruh WP yang mengikuti pengampunan pajak di KPP Pratama Manado Tahun 2016-2017.

Sampel adalah bagian dari jumlah dan karakteristik yang dimiliki oleh populasi (Sugiyono, 2014:116). Pengambilan sampel dilakukan menggunakan Convenience Sampling. Penarikan sampel ini sangat sederhana, yaitu karena hanya sekedar kebetulan, yaitu siapa saja yang secara kebetulan bertemu peneliti yang dianggap cocok sumber data ( Riadi, 2016: 36). Besarnya sampel dalam penelitian ini ditentukan menggunakan rumus Slovin berikut ini :

$$
\mathrm{n}=\frac{\mathrm{N}}{1+\left(\mathrm{Nxe}^{2}\right)}
$$

Keterangan:

$\mathrm{n}=$ Ukuran sampel

$\mathrm{N}=$ Populasi

$\mathrm{e}=$ Prosentase kelonggaran ketidakterikatan karena kesalahan pengambilan sampel yang masih diinginkan

\subsection{Metode Pengumpulan Data}

(Sujarsweni, 2015:80)

\subsubsection{Jenis Data}

Jenis data yang digunakan dalam penelitian ini adalah data kuantitatif yang berupa nilai atau skor atas jawaban yang diberikan oleh responden terhadap pertanyaan-pertanyaan yang terdapat dalam kuesioner.

\subsubsection{Sumber Data}

Sumber data yang digunakan dalam penelitian ini adalah data primer yang secara langsung bersumber dari responden tanpa ada perantara, dalam hal ini adalah dari jawaban atas pertanyaan-pertanyaan yang ada dalam kuesioner. Data primer yang dihasilkan dalam penelitian ini adalah merupakan hasil dari tanggapan responden terhadap variabel-variabel penelitian yang akan diuji.

\subsection{Metode Analisis Data}

Metode analisis data yang digunakan dalam penelitian ini adalah analisis regresi linier berganda (Multiple Regression Analysis) dengan bantuan program Statistical Product and Service Solution (SPSS).

\subsubsection{Statistik Deskriptif}

Statistik deskriptif adalah statistik yang digunakan untuk menganalisis data cara mendeskripsikan atau menggambarkan data yang telah terkumpul sebagaimana adanya tanpa bermaksud membuat kesimpulan yang berlaku umum atau generalisasi (I'anatut Thoifah, 2015:75).

\subsubsection{Uji Kualitas Data}

\subsubsection{Uji Validitas}

Sebuah kuesioner yang digunakan dalam penelitian harus valid. Arti valid disini yaitu mampu menunjukkan sampai sejauh mana alat ukur mampu mengukur apa yang ingin diukur. Pada uji validitas ini, digunakan korelasi product moment pearson (metode interkorelasi). Cara pengukurannya yaitu menghitung korelasi antara skor masing-masing item pertanyaan pada kuesioner skor total kuesioner. Jika nilai $r_{\text {hitung }}>r_{\text {tabel }}$ dan atau nilai sig $<0,05$ maka item pertanyaan tersebut dianggap valid (I'anatut Thoifah, 2015:111).

\subsubsection{Uji Reliabilitas}

Reliabel yaitu dimana suatu alat ukur mampu menunjukkan sampai sejauh mana alat ukur tersebut dapat dipercaya atau diandalkan. Cara pengukurannya adalah seluruh item pertanyaan yang telah valid dimasukkan dan diukur koefisien Alpha Cronbachnya. Jika nilai 
$r_{\text {hitung }}$ yang diperoleh lebih besar dari $r_{\text {tabel }}$ berdasarkan maka data reliabel. Teknik ini dapat digunakan untuk menentukan apakah suatu instrumen penelitian reliabel atau tidak.

\subsubsection{Asumsi Klasik}

\subsubsection{Uji Multikolinearitas}

Menurut Ghozali (2013:105), uji multikolinearitas bertujuan untuk menguji apakah model regresi ditemukan adanya korelasi antar variabel bebas (independen). Model regresi yang baik seharusnya tidak terjadi korelasi antar variabel independen. Kemiripan antar variabel independen dalam satu model akan menyebabkan terjadinya korelasi yang sangat kuat antara satu variable independen dengan variabel independen yang lain. Ada atau tidaknya multikolinearitas dapat dilihat dari Variance Inflation Factor (VIF). Jika nilai VIF tidak lebih dari 10 dan nilai toleransi tidak kurang dari 0,1 maka model dapat dikatakan terbebas dari multikolinearitas (Putri, 2016).

\subsubsection{Uji Heteroskedastisitas}

Menurut Ghozali (2013:139) uji heteroskedastisitas yaitu untuk menguji apakah dalam sebuah model regresi terjadi ketidaksamaan varians dari residual satu pengamatan kepengamatan yang lain. Model regresi yang baik adalah tidak terjadinya heteroskedastisitas (Putri, 2016). Untuk mendeteksi ada tidaknya heteroskedastisitas adalah melihat hasil Grafik Plot antara nilai prediksi variable dependen pada sumbu Y residualnya (Y prediksi - Y sesungguhnya) pada sumbu $\mathrm{X}$ di mana terjadi penyebaran dari titik nol atau tidak. Jika titiktitik menyebar pola yang tidak jelas di atas dan di bawah angka 0 pada sumbu Y, maka tidak terjadi masalah heteroskedastisitas.

\subsubsection{Uji Normalitas}

Menurut Ghozali (2013:160) mengemukakan bahwa uji normalitas bertujuan untuk mengetahui apakah masing-masing variabel berdistribusi normal atau tidak. Untuk menguji suatu data berdistribusi normal atau tidak, dapat diketahui dengan menggunakan grafik normal plot. Dasar pengambilan keputusan, jika data menyebar disekitar garis diagonal dan mengikuti arah garis diagonal atau grafik histogramnya menunjukkan pola distribusi normal, maka model regresi memenuhi asumsi normalitas.

\subsubsection{Uji Hipotesis}

Uji hipotesis diuji menggunakan metode analisis regresi berganda. Dalam penelitian ini, analisis regresi linier berganda digunakan untuk membuktikan sejauh mana hubungan pengaruh Motivasi, Tingkat Pendidikan dan Sosialisasi terhadap Kemauan Mengikuti Pengampunan Pajak.

\subsubsection{Uji Koefisien Determinasi $\left(\mathbf{R}^{2}\right)$}

Menurut Ghozali (2013:97), koefisien determinasi $\left(\mathrm{R}^{2}\right)$ pada intinya mengukur seberapa jauh kemampuan model dalam menerangkan variasi variabel dependen. Uji Koefisien Determinasi $\left(\mathrm{R}^{2}\right)$ dilakukan untuk mengetahui seberapa besar persentase sumbangan dari variabel independen secara bersama-sama terhadap variabel dependen.

\subsubsection{Uji Parsial ( Uji t)}

Menurut Sugiyono (2014: 194) uji t digunakan untuk mengetahui masing-masing sumbangan variabel bebas secara parsial terhadap variabel terikat, menggunakan uji masingmasing koefisien regresi variabel bebas apakah mempunyai pengaruh yang bermakna atau tidak terhadap variabel terikat.

Untuk mencari $\mathrm{t}$ tabel dihitung $\mathrm{df}=\mathrm{n}-\mathrm{k}-1$, dimana $\mathrm{n}$ adalah jumlah responden dan $\mathrm{k}$ adalah jumlah variabel. Taraf nyata $5 \%$ dapat dilihat menggunakan tabel statistik. Nilai $t_{\text {tabel }}$ dapat dilihat menggunakan tabel t. Dasar pengambilan keputusan adalah.

a. Jika $\mathrm{t}_{\text {hitung }}>\mathrm{t}_{\text {tabel}}$, maka $\mathrm{H}_{\mathrm{a}}$ diterima dan $\mathrm{H}_{\mathrm{o}}$ ditolak

b. Jika $\mathrm{t}_{\text {hitung }}<\mathrm{t}_{\text {tabel }}$, maka $\mathrm{H}_{\mathrm{a}}$ ditolak dan $\mathrm{H}_{\mathrm{o}}$ diterima. 


\subsubsection{Uji Pengaruh Simultan (Uji F)}

Uji F digunakan untuk mengetahui apakah secara simultan koefisien variabel bebas mempunyai pengaruh nyata atau tidak terhadap variabel terikat. Menurut Sugiyono (2014: 257), F perhitungan ini dibandingkan yang diperoleh menggunakan tingkat resiko atau $\alpha=$ 0,05 atau degree freedom $=\mathrm{k}(\mathrm{n}-\mathrm{k})$ kriteria sebagai berikut :

a. $\mathrm{H}_{\mathrm{o}}$ ditolak jika $\mathrm{F}_{\text {hitung }}>\mathrm{F}_{\text {tabel }}$ atau nilai sig $<\alpha$

b. $\mathrm{H}_{\mathrm{o}}$ diterima jika $\mathrm{F}_{\text {hitung }}<\mathrm{F}_{\text {tabel }}$ atau nilai sig $>\alpha$

\subsection{Definisi dan Pengukuran Variabel}

\subsubsection{Variabel Dependen}

\subsubsection{Kemauan Mengikuti Pengampunan Pajak}

Variabel dependen dalam penelitian ini adalah Kemauan Mengikuti Pengampunan Pajak. Kemauan Mengikuti Pengampunan pajak adalah keinginan dari seseorang yang diwujudkan dalam suatu tindakan untuk menyediakan dokumen pengampunan pajak dan mencari informasi tentang pengampunan pajak sehingga mengetahui batas waktu pengampunan pajak dan cara untuk mengikuti pengampunan pajak.

\subsubsection{Variabel Independen}

Variabel independen dalam penelitian ini yaitu; Motivasi Wajib Pajak, Tingkat Pendidikan Wajib Pajak, dan Sosialisasi.

\subsubsection{Motivasi}

Motivasi adalah suatu dorongan sesorang mengikuti pengampunan pajak. Dorongan tersebut bisa dari dalam diri seseorang maupun dari luar. Motivasi dari dalam diri seseorang untuk mengikuti pengampunan pajak yaitu kesadaran seseorang, bahwa setiap wajib pajak memiliki kewajiban untuk membayar pajak sehingga sukarela melaporkan seluruh kewajibannya serta mengetahui fungsi dari pajak yang dibayarkannya. Motivasi seseorang yang dipengaruhi dari luar berupa pengaruh dari keluarga, teman-teman atau kerabat serta lingkungan kerja dari seseorang.

\subsubsection{Tingkat Pendidikan}

Tingkat Pendidikan adalah jenjang pendidikan yang telah ditempuh oleh masyarakat meliputi:

1. Pendidikan Dasar, yang terdiri dari SD dan SMP

2. Pendidikan Menengah, yang terdiri dari SMA

3. Pendidikan Tinggi, yang mencakup program pendidikan Diploma, Sarjana, Magister, dan Doktor yang diselenggarakan oleh lembaga pendidikan tinggi.

Variabel pendidikan ini merupakan variabel semi kuantitatif, sehingga penelitian dibatasi hanya pada pendidikan formal WP yaitu:

1. SD-SMU (Non Perguruan Tinggi) 2. Perguruan Tinggi.

\subsubsection{Sosialisasi}

Sosialisasi adalah suatu upaya dari DJP untuk memberikan informasi tentang pengampunan pajak kepada masyarakat pada umumnya dan wajib pajak pada khususnya, sehingga seluruh masyarakat bisa menerima informasi dan memahami tentang program pengampunan pajak.

\section{HASIL PENELITIAN DAN PEMBAHASAN \\ 4.1 Hasil Penelitian}

\subsubsection{Analisis Data}

\subsubsection{Uji Validitas}

Berikut ini adalah beberapa tabel hasil dari pengujian validitas butir instrumen Kemauan Mengikuti Pengampunan Pajak, Motivasi, dan sosialisasi menggunakan program SPSS versi 20.0 : 
Tabel 4.6 Hasil Uji Validitas Kemauan Mengikuti Pengampunan Pajak

\begin{tabular}{cccc}
\hline Pertanyaan & r hitung & r tabel & Keterangaan \\
\hline 1 & 0,265 & 0,195 & Valid \\
\hline 2 & 0,788 & 0,195 & Valid \\
\hline 3 & 0,626 & 0,195 & Valid \\
\hline 4 & 0,454 & 0,195 & Valid \\
\hline 5 & 0,604 & 0,195 & Valid
\end{tabular}

Sumber: Data primer yang diolah (2017)

Tabel 4.7 Hasil Uji Validitas Motivasi

\begin{tabular}{lccc}
\hline Pertanyaan & r hitung & r tabel & Keterangan \\
\hline 1 & 0,335 & 0,195 & Valid \\
\hline 2 & 0,303 & 0,195 & Valid \\
\hline 3 & 0,356 & 0,195 & Valid \\
\hline 4 & 0,309 & 0,195 & Valid \\
\hline 5 & 0,682 & 0,195 & Valid \\
\hline 6 & 0,597 & 0,195 & Valid \\
\hline
\end{tabular}

Sumber: Data primer yang diolah (2017)

Tabel 4.8 Hasil Uji Validitas Sosialisasi

\begin{tabular}{cccc}
\hline Pertanyaan & r hitung & r tabel & Keterangaan \\
\hline 1 & 0,462 & 0,195 & Valid \\
\hline 2 & 0,707 & 0,195 & Valid \\
\hline 3 & 0,675 & 0,195 & Valid \\
\hline 4 & 0,1634 & 0,195 & Valid
\end{tabular}

Sumber : Data primer yang diolah (2017)

Dari hasil analisis validitas data yang ada, menunjukkan bahwa bila koefisien korelasi sama $r_{\text {tabel }}(0,195)$ atau lebih, maka butir instrument dikatakan valid. Oleh karena itu semua butir pertanyaan dari variabel Kemauan Mengikuti Pengampunan Pajak, Motivasi, dan Sosialisasi adalah valid dan dapat digunakan.

\subsubsection{Uji Reliabilitas}

Berikut adalah hasil perhitungan reliabilitas angket uji coba penelitian untuk variabel Kemauan Mengikuti Pengampunan Pajak, variabel Motivasi, dan variabel Sosialisasi. 
Tabel 4.9 Hasil Uji Reliabilitas

\begin{tabular}{cccc}
\hline Variabel & r hitung & r tabel & Keterangan \\
\hline Kemauan Mengikuti Pengampunan Pajak & 0,433 & 0,195 & Reliabel \\
\hline Motivasi & 0,233 & 0,195 & Reliabel \\
\hline Sosialisasi & 0,463 & 0,195 & Reliabel \\
\hline
\end{tabular}

Sumber: Data primer yang di olah (2017)

\subsubsection{Hasil Uji Asumsi Klasik}

\subsubsection{Uji Multikolinearitas}

Hasil dari pengolahan data uji multikolinearitas program SPSS versi 20.0 dapat dilihat pada Tabel 4.10.

Tabel 4.10 Hasil Uji Multikolinearitas

\begin{tabular}{|c|c|c|c|}
\hline & \multirow[t]{2}{*}{ Model } & \multicolumn{2}{|c|}{ Collinearity Statistics } \\
\hline & & Tolerance & VIF \\
\hline \multicolumn{4}{|c|}{ (Constant) } \\
\hline \multirow{3}{*}{1} & Motivasi & .933 & 1.072 \\
\hline & Tingkat Pendidikan & .990 & 1.010 \\
\hline & Sosialisasi & .925 & 1.082 \\
\hline
\end{tabular}

Sumber: Data yang diolah (2017)

Dari data yang ada pada Tabel 4.10, diketahui bahwa hasil perhitungan nilai tolerance menunjukkan tidak ada variabel independen yang memiliki nilai tolerance lebih dari 10, yang berarti tidak ada korelasi antar variabel independen yang nilainya lebih dari 95\%. Hasil perhitungan nilai Variance Inflation Factor (VIF) juga menunjukkan nilai VIF kurang dari 10. Jadi dapat disimpulkan bahwa tidak terjadi multikolinearitas antar variabel dalam model regresi penelitian ini.

\subsubsection{Uji Heteroskedastisitas}

Hasil dari pengolahan uji heteroskedastisitas program SPSS versi 20.0 dapat dilihat pada Gambar 4.2.

$$
\begin{aligned}
& \text { Gambar 4.2 Grafik Scatterplots } \\
& \text { Scatterplot }
\end{aligned}
$$

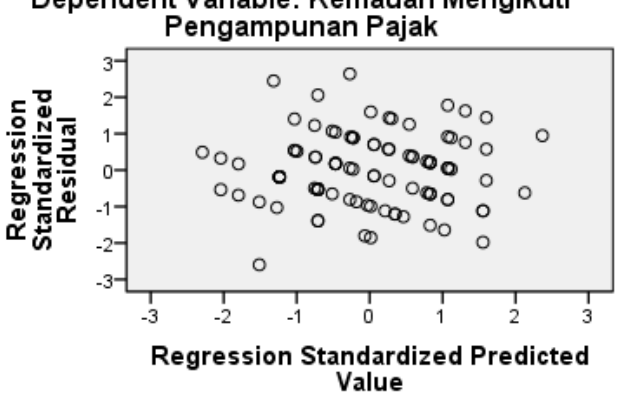

Sumber: Data primer yang diolah (2017)

Dari Gambar 4.2 terlihat bahwa titik-titik menyebar secara acak serta tersebar di atas maupun di bawah angka nol (0) pada sumbu Y. Hal ini dapat disimpulkan bahwa tidak terjadi heteroskedastisitas pada model regresi penelitian ini. 


\subsubsection{Uji Normalitas}

Hasil dari pengolahan data uji normalitas menggunakan program SPSS versi 20.0 dapat dilihat pada Gambar 4.3.

\section{Gambar 4.3 Grafik Normal Plot}

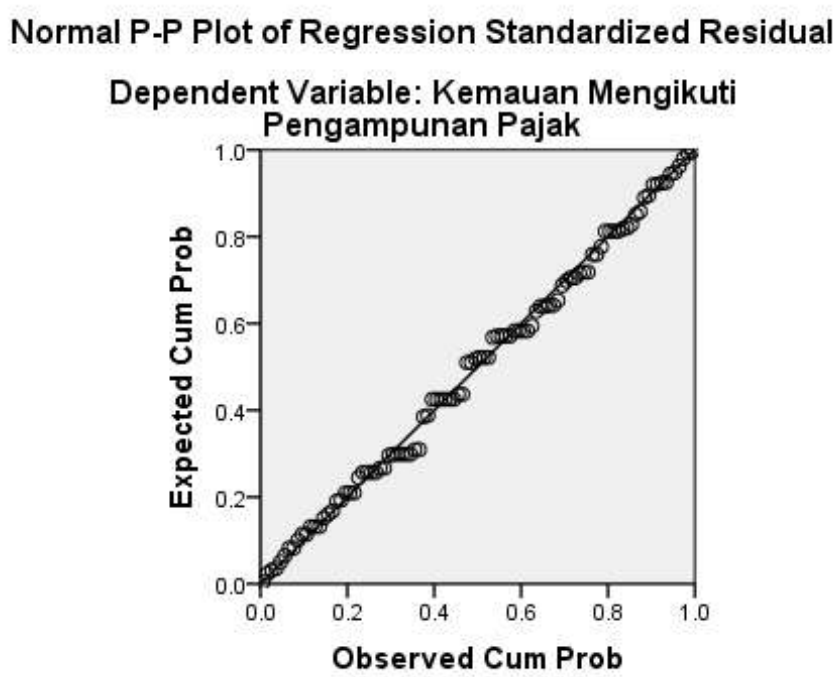

Sumber: Data primer yang diolah (2017)

Melihat tampilan pada Gambar 4.3, terlihat titik-titik menyebar di sekitar garis diagonal dan mengikuti arah garis diagonal. Hal ini menunjukkan bahwa model regresi dalam penelitian ini memenuhi asumsi normalitas.

\subsubsection{Hasil Uji Hipotesis}

Berdasarkan hasil uji asumsi klasik dapat disimpulkan bahwa model regresi yang digunakan dalam penelitian ini layak dilakukan analisis regresi. Pengujian hipotesis dalam penelitian ini dilakukan analisis linear berganda.

Dalam uji hipotesis ini dilakukan melalui:

\subsubsection{Hasil Uji Koefisien Determinasi}

Uji Koefisien Determinasi yang dilakukan untuk mengetahui persentase sumbangan pengaruh variabel independen secara serentak terhadap variabel dependen.

\section{Tabel 4.11 Hasil Uji Linier Berganda Koefisien Determinasi}

Model Summary

\begin{tabular}{|c|r|r|r|c|}
\hline Model & R & R Square & \multicolumn{1}{c|}{$\begin{array}{c}\text { Adjusted R } \\
\text { Square }\end{array}$} & $\begin{array}{c}\text { Std. Error of the } \\
\text { Estimate }\end{array}$ \\
\hline 1 & $.554^{\mathrm{a}}$ & .307 & .286 & 1.82757 \\
\hline
\end{tabular}

a. Predictors: (Constant), Sosialisasi, Tingkat Pendidikan, Motivasi

Sumber: Data primer yang diolah (2017)

Berdasarkan Tabel 4.11, dapat diketahui bahwa nilai koefisien determinasi ganda (Adjusted $\mathrm{R}^{2}$ ) sebesar 0,286. Nilai ini menunjukkan bahwa Kemauan Wajib Pajak Mengikuti Pengampunan Pajak di KPP Pratama Manado dipengaruhi oleh 28,6\% variabel Motivasi, Tingkat Pendidikan dan Sosialisasi.

\subsubsection{Hasil Uji Parsial (Uji t)}

Uji parsial (uji t), yang dilakukan untuk mengetahui hubungan varibel independen secara individual (parsial) terhadap variabel dependen. 
Tabel 4.12 Hasil Uji Linier Berganda Uji t Coefficients $^{a}$

\begin{tabular}{|c|c|c|c|c|c|c|}
\hline & \multirow[t]{2}{*}{ Model } & \multicolumn{2}{|c|}{ Unstandardized Coefficients } & \multirow{2}{*}{$\frac{\text { Standardized Coefficients }}{\text { Beta }}$} & \multirow[t]{2}{*}{$\mathrm{t}$} & \multirow[t]{2}{*}{ Sig. } \\
\hline & & $\mathrm{B}$ & Std. Error & & & \\
\hline \multirow{4}{*}{1} & (Constant) & .504 & 1.594 & & .316 & .753 \\
\hline & Motivasi & .217 & .084 & .228 & 2.576 & .012 \\
\hline & $\begin{array}{c}\text { Tingkat } \\
\text { Pendidikan }\end{array}$ & .929 & .461 & .173 & 2.018 & .046 \\
\hline & Sosialisasi & .418 & .092 & .403 & 4.531 & .000 \\
\hline
\end{tabular}

a. Dependent Variable: Kemauan Mengikuti Pengampunan Pajak

1. Pengaruh Motivasi terhadap Kemauan Wajib Pajak Mengikuti Pengampunan Pajak di KPP Pratama Manado $\left(\mathrm{H}_{1}\right)$

Berdasarkan Tabel 4.12, diketahui nilai signifikan dari variabel Motivasi lebih kecil dari $\alpha=5 \%(0,012<0,05)$ dan nilai $t_{\text {hitung }}$ lebih besar dari $t_{\text {tabel }}(2,576<1,986)$, sehingga dapat disimpulkan bahwa Motivasi berpengaruh terhadap Kemauan WP Mengikuti Pengampunan Pajak di KPP Pratama Manado.

2. Pengaruh Tingkat Pendidikan terhadap Kemauan WP Mengikuti Pengampunan Pajak di KPP Pratama Manado $\left(\mathrm{H}_{2}\right)$

Berdasarkan Tabel 4.12, deketahui nilai signifikan dari variabel Tingkat Pendidikan lebih kecil dari $\alpha=5 \%(0,046>0,05)$ dan nilai $t_{\text {hitung }}$ lebih besar dari $t_{\text {tabel }}(2,018<1,986)$, sehingga dapat disimpulkan bahwa Tingkat Pendidikan berpengaruh terhadap Kemauan WP Mengikuti Pengampunan Pajak di KPP Pratama Manado.

3. Pengaruh Sosialisasi terhadap Kemauan Wajib Pajak Mengikuti Pengampunan Pajak di KPP Pratama Manado $\left(\mathrm{H}_{3}\right)$

Berdasarkan Tabel 4.12, diketahui nilai signifikan dari variabel Sosialisasi lebih kecil dari $\alpha=5 \%(0,00<0,05)$ dan nilai $\mathrm{t}_{\text {hitung }}$ lebih besar dari $\mathrm{t}_{\text {tabel }}(4,531>1.986)$, sehingga dapat disimpulkan bahwa Sosialisasi berpengaruh terhadap Kemauan WP Mengikuti Pengampunan Pajak di KPP Pratama Manado.

\subsubsection{Hasil Uji Simultan (Uji F)}

Uji $F$ yang dilakukan adalah untuk mengetahui apakah variabel independen secara bersama-sama berpengaruh terhadap variabel dependen. Pengaruh Motivasi, Tingkat Pendidikan, dan Sosialisasi terhadap Kemauan Wajib Pajak Mengikuti Pengampunan Pajak di KPP Pratama Manado.

\section{Tabel 4.13 Hasil Uji Linier Berganda Uji F} ANOVA $^{\mathrm{a}}$

\begin{tabular}{|c|c|c|c|c|c|c|}
\hline & Model & Sum of Squares & $\mathrm{df}$ & Mean Square & $\mathrm{F}$ & Sig. \\
\hline \multirow{3}{*}{1} & Regression & 142.177 & 3 & 47.392 & 14.189 & $.000^{\mathrm{b}}$ \\
\hline & Residual & 320.640 & 96 & 3.340 & & \\
\hline & Total & 462.817 & 99 & & & \\
\hline
\end{tabular}

a. Dependent Variable: Kemauan Mengikuti Pengampunan Pajak

b. Predictors: (Constant), Sosialisasi, Tingkat Pendidikan, Motivasi

Sumber : Data primer diolah (2017)

Pada Tabel 4.13, diketahui nilai $F_{\text {hitung }}$ sebesar 14,189, jika dibanding $F_{\text {tabel }}$ pada tingkat signifikansi $5 \%$ yaitu sebesar 2,70 maka nilai $F_{\text {hitung }}$ lebih besar dari nilai $\mathrm{F}_{\text {tabel }}($ 14,189>2,70). Nilai signifikansi sebesar 0,000 pada tabel diatas menunjukkan bahwa Motivasi, Tingkat Pendidikan dan Sosialisasi berpengaruh terhadap Kemauan WP Mengikuti Pengampunan Pajak di KPP Pratama Manado. Hal ini disebabkan karena nilai signifikansi 0,000 lebih kecil dari nilai $\alpha=5 \%$. 


\subsection{Pembahasan Hasil Penelitian}

\subsubsection{Pengaruh Motivasi terhadap Kemauan Mengikuti Pengampunan Pajak}

Hipotesis yang menyatakan bahwa Kemauanan Wajib Pajak Mengikuti Pengampunan Pajak diduga akan dipengaruhi oleh variabel motivasi telah terbukti. Pembuktian dilakukan melalui uji analisis regresi linier berganda. Dari uji tersebut, didapatkan hasil penelitian menunjukkan Motivasi berpengaruh terhadap Kemauan Wajib Pajak Mengikuti Pengampunan Pajak di KPP Pratama Manado. Hal ini dapat dilihat dari nilai koefisien regresi yang bernilai positif yaitu 0,217 dan nilai $t_{\text {hitung }}$ lebih besar daripada nilai $t_{\text {tabel }}(2,576>1,986)$ pada tingkat signifikansi 5\%. Selain itu, nilai signifikansi variabel Motivasi terhadap Kemauan Wajib Pajak Mengikuti Pengampunan Pajak di KPP Pratama Manado lebih kecil dibandingkan nilai signifikansi $\alpha=5 \% \quad(0,012<0,05)$ yang menunjukkan bahwa variabel Motivasi berpengaruh terhadap Kemauan Wajib Pajak Mengikuti Pengampunan Pajak di KPP Pratama Manado.

\subsubsection{Pengaruh Tingkat Pendidikan terhadap Kemauan Mengikuti Pengampunan Pajak}

Hasil penelitian menunjukkan Tingkat Pendidikan berpengaruh terhadap Kemauan Wajib Pajak Mengikuti Pengampunan Pajak di KPP Pratama Manado. Hal ini dapat dilihat dari nilai koefisien regresi yang bernilai positif yaitu 0,929 dan nilai $t_{\text {hitung }}$ lebih besar daripada nilai $t_{\text {tabel }}(2,018>1,986)$ pada tingkat signifikansi $5 \%$. Selain itu, nilai signifikansi variabel Tingkat Pendidikan terhadap Kemauan Wajib Pajak Mengikuti Pengampunan Pajak di KPP Pratama Manado lebih kecil dibandingkan nilai signifikansi $\alpha=5 \% \quad(0,046<0,05)$ yang menunjukkan bahwa variabel Tingkat Pendidikan berpengaruh signifikan terhadap Kemauan Wajib Pajak Mengikuti Pengampunan Pajak di KPP Pratama Manado.

\subsubsection{Pengaruh Sosialisasi terhadap Kemauan Mengikuti Pengampunan Pajak}

Hasil penelitian menunjukkan Sosialisasi berpengaruh terhadap Kemauan Wajib Pajak Mengikuti Pengampunan Pajak di KPP Pratama Manado. Hal ini dapat dilihat dari nilai koefisien regresi yang bernilai positif yaitu 0,418 dan nilai $\mathrm{t}_{\text {hitung }}$ lebih besar daripada nilai $\mathrm{t}$ tabel $(4,531>1,986)$ pada tingkat signifikansi 5\%. Selain itu, nilai signifikansi variabel Sosialisasi terhadap Kemauan Wajib Pajak Mengikuti Pengampunan Pajak di KPP Pratama Manado lebih kecil dibandingkan nilai signifikansi $\alpha=5 \%(0,000<0,05)$, yang menunjukkan bahwa variabel Sosialisasi berpengaruh signifikan terhadap Kemauan Wajib Pajak Mengikuti Pengampunan Pajak di KPP Pratama Manado.

\subsubsection{Pengaruh Motivasi, Tingkat Pendidikan, dan Sosialisasi terhadap Kemauan mengikuti Pengampunan Pajak}

Hasil penelitian menunjukkan bahwa variabel Motivasi, Tingkat Pendidikan, dan Sosialisasi berpengaruh terhadap Kemauan Wajib Pajak Mengikuti Pengampunan Pajak di KPP Pratama Manado. Hal ini dapat dilihat pada nilai $F_{\text {hitung }}$ lebih besar 14,189 dibandingkan $F_{\text {tabel }}$ pada tingkat signifikansi 5\% yaitu sebesar 2,70 (14,189>2,70). Nilai signifikansi sebesar 0.000 menunjukkan bahwa Motivasi, Tingkat Pendidikan dan Sosialisasi berpengaruh signifikan terhadap Kemauan Wajib Pajak Mengikuti Pengampunan Pajak di KPP Pratama Manado. Hal ini disebabkan karena nilai signifikansi 0,000 lebih kecil dari nilai $\alpha=5 \%$ $(0,05)$.

Nilai koefisien determinasi ganda (Adjusted $\mathrm{R}^{2}$ ) sebesar 0,286. Nilai ini menunjukkan bahwa Kemauan Wajib Pajak Mengikuti Pengampunan Pajak di KPP Pratama Manado dipengaruhi oleh 28,6\% variabel Motivasi, Tingkat Pendidikan dan Sosialisasi, sisanya $71,4 \%$ dipengaruhi oleh variabel lain yang tidak dijelaskan dalam penelitian ini. 


\section{KESIMPULAN DAN SARAN}

\subsection{Kesimpulan}

1. Motivasi berpengaruh terhadap Kemauan Wajib Pajak Mengikuti Pengampunan Pajak di KPP Pratama Manado. Hal ini dibuktikan nilai koefisien regresi yang bernilai positif yaitu

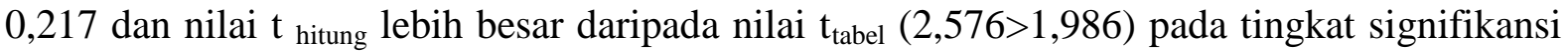
$5 \%$. Selain itu, nilai signifikansi lebih kecil dibandingkan nilai signifikansi $\alpha=5 \%$ $(0,012<0,05)$.

2. Tingkat Pendidikan berpengaruh terhadap Kemauan Wajib Pajak Mengikuti Pengampunan Pajak di KPP Pratama Manado. Hal ini dibuktikan koefisien regresi yang bernilai positif 0,929 dan nilai $t$ hitung lebih besar daripada nilai $t$ tabel $(2,018>1,986)$ pada tingkat signifikansi 5\%. Selain itu, nilai signifikansi lebih kecil dibandingkan nilai signifikansi $\alpha=5 \%(0,046<0,05)$.

3. Sosialisasi berpengaruh terhadap Kemauan Wajib Pajak Mengikuti Pengampunan Pajak di KPP Pratama Manado. Hal ini dibuktikan koefisien regresi yang bernilai positif yaitu 0,418 dan nilai $\mathrm{t}$ hitung lebih besar daripada nilai $\mathrm{t}$ tabel $(4,531>1,986)$ pada tingkat signifikansi 5\%. Selain itu, nilai signifikansinya lebih kecil dibandingkan nilai signifikansi $\alpha=5 \%(0,000<0,05)$.

4. Motivasi, Tingkat Pendidikan dan Sosialisasi bersama-sama berpengaruh terhadap Kemauan Wajib Pajak Mengikuti Pengampunan Pajak di KPP Pratama Manado. Hal ini dibuktikan pada nilai $\mathrm{F}_{\text {hitung }}$ lebih besar 14,189 dibandingkan $\mathrm{F}_{\text {tabel }}$ pada tingkat signifikansi $5 \%$ yaitu sebesar 2,70 $(14,189>2,70)$. Nilai signifikansinya lebih kecil dari nilai $\alpha=5 \%$ $(0,000<0,05)$.

\subsection{Saran}

Berdasarkan hasil penelitian dan kesimpulan, maka saran-saran yang dapat diberikan berkaitan judul adalah sebagai berikut :

1. Motivasi dalam diri wajib pajak sosialisasi dari DJP sangat perlu untuk ditingkatkan oleh DJP untuk mendorong wajib pajak terlibat dalam program pengampunan pajak yang dilaksanakan oleh DJP pada masa yang akan datang.

2. Bagi penelitian selanjutnya dapat menggunakan variabel lain sehingga dapat ditemukan variabel baru yang mendorong kemauan wajib pajak untuk mengikuti program pengampunan pajak.

\section{DAFTAR PUSTAKA}

Agus Iwan Kusuma, 2016. Pengampunan Pajak (Tax Amnesty) Sebagai Upaya Optimalisasi Fungsi Pajak. Jurnal Ekonomi Keuangan, dan Manajemen, Volume 12, No 2 (2016)

Amilin, Yusronillah, 2009. Analisis Pengaruh Tingkat Pendidikan Dan Jenis Pekerjaan Wajib Pajak Terhadap Motivasi Dalam Memenuhi Kewajiban Pajak. JMK Vol 7. No. 3

Arikunto, Suharsimi. 2013. Prosedur Penelitian Suatu Pendekatan Praktik. Rineka Cipta, Jakarta.

Dwi Purnama Putri, 2014. Pengaruh Sosialisasi Perpajakan Dan Help Desk Terhadap Kepatuhan Wajib Pajak (Studi Pada Kantor Pelayanan Pajak Pratama Cianjur). EProceeding of Management Vol. 1, No.3

Farrar, J. \& Hausserman, C., 2016, “ An Exploratory Investigation of Extrinsic and Intrinsic Motivations in Tax Amnesty Decision-Making”. Journal of Tax Administration, 2(2), 47-66.

Husen Abdul Ghoni, 2012. "Pengaruh Motivasi dan Pengetahuan Wajib Pajak terhadap Kepatuhan Wajib Pajak Daerah”. Jurnal Riset Manajemen dan Akuntansi UNESA Vol.1 No.1. Jurusan Akuntansi Univeritas Negeri Surabaya 
Ghozali, Imam. 2013. Aplikasi Analisis Multivariate dengan Program SPSS. Edisi KetujuhSemarang : Badan Penerbit Universitas Dipenogoro

Harryanto, Marisa, dan Toly, 2013. "Pengaruh Kesadaran Wajib Pajak, Kegiatan Sosialisasi Perpajakan, dan Pemeriksaan Pajak Terhadap Penerimaan Pajak Penghasilan di KPP Pratama Surabaya Sawahan".Tax \& Accounting Review, Vol.1, No.1

Mehmet, 2015."The effects of Behavioral Economics on Tax Amnesty". Internasional Journal of Economi and Financial Issue, 2015, 5(2), 580-589

Roralita Lukmana Putri, 2016. Pengaruh Motivasi Membayar Pajak Dan Tingkat Pendidikan Terhadap Kepatuhan Wajib Pajak Orang Pribadi Pada Kantor Wilayah Direktorat Jenderal Pajak Daerah Istimewa Yogyakarta Tahun 2015. Yogyakarta

Ryan R, Deci E, 2000, "Intrinsic and Ekstrinsic Motivations: Classic Definition and New Directions". Contemporary Educational Psychology 25, 54-67

Siahaan, 2017.Tax Amnesty di Indonesia.Jakarta

Sujarweni, 2015.Statistik untuk Bisnis \& Ekonomi. Yogyakarta

Sumarsan,2013.Perpajakan Indonesia. Edisi Ketiga. Jakarta 